\title{
周波数および位相差ファジィハイブリッド制御による 超音波モータ二自由度位置サーボシステム
}

\begin{tabular}{|c|c|c|c|c|c|c|c|c|}
\hline 員 & 福 & 田 & 耕 & 治 & & & & 气校) \\
\hline 員 & 鎌 & 野 & 玩 & 也 & （德 & 島 & 大 & 学) \\
\hline 員 & 安 & 野 & & 卓 & (德 & 島 & 大 & \\
\hline 員 & 鈴 & 木 & 茂 & 行 & （德 & 島 & 大 & \\
\hline
\end{tabular}

Two-degree-of-freedom Servo System with Ultrasonic Motor by Frequency and Phase Fuzzy Hybrid Control

Fukuda Koji, Member (Anan College of Technology), Kamano Takuya, Member, Yasuno Takashi, Member, Suzuki Takayuki, Member (The University of Tokushima)

In this paper, a two-degree-of freedom control system with fuzzy controllers for the progressive wave type ultrasonic motor (PUM) is proposed. The system consists of a fuzzy feedforward controller (FFC) and a fuzzy disturbance observer (FDO). The FFC adjusts both the driving frequency and the phase, of which objective is to improve the tracking performances. The frequency and the phase control rules of the FFC are tuned so that the tracking error converges to zero. After tuning process is completed, the fuzzy rules which represent the equivalent dynamic inverse are obtained in the FFC. The tuned fuzzy rules of the FFC are copied and used to estimate the applied disturbance in the FDO. The responses of the proposed positioning system for the desired output and the disturbance are measured. Experimental results demonstrate the effectiveness of the proposed system for improvement of the tracking performances and suppression of the disturbance input.

キーワード：超音波モータ, 自己調整ファジィ制御, 外乱オブザーバ, 二自由度制御

\section{1. まえがき}

進行波型超音波モータ (PUM) は, 小型モーションコン トロールシステムのアクチュエータとして期待される種々 の特長を有している(1)。しかし，同モータは本質的に非線 形特性を有し，特性も大きく変動する。このため，固定ゲ インを用いた従来のフィードバックコントローラによる制 御手法では限界がある。

そこで，近年，適応制御 (2)(3)やファジィ制御 (4)-(6)，二 ユーラルネットワータ(7)(8)を用いた制御などの制御手法が 提案されている。また, 一般に, 超音波モー夕は入力する 2 相駆動電圧の振幅・周波数・位相差によって駆動特性が 变化する。このため，制御性能の点からは単独ではなく、 駆動周波数や位相差を組み合わせて制御する方が有利であ る(3)(4)。しかし，これまでの制御手法のほとんどは単独に 周波数または位相差を操作寸るシステムである。また，複 数のパラメー夕を操作する場合であっても固定ルールを用 いるファジィ制御ではルールの構築が煩雑となるなとの問 題があった(4)。
そこで，筆者らはこれまでに周波数ニューラルネットワー クと位相差ニューラルネットワークの二つのニューラルネッ トワークを組み合わせ，周波数と位相差を操作する位置決 めシステムを提案している(8)。このシステムにより，単独 のニューラルネットワークを適用した位置決めシステムに 比べて，良好な追従および位置決め特性が得られることを 確認している。しかし，ニューラルネットワークでは，そ の結合係数の初期値を微小值とするのが一般的であり，原 理的に制御開始時にその值の意味を決定することはできな い。このため，システムを高速かつ安定にチューニングさ せるためには，二つのニューラルネットワークのチューニ ングが同程度に進行するように学習ゲインの大きさとバラ ンスを考慮する必要があった。また，同システムでは主と して規範入力追従特性に着目しており，外乱抑圧特性につ いては十分な検討がなされていない。

本稿では，PIフィードバックループに周波数ファジィコ ントローラと位相差ファジィコントローラをフィードフォ ワード接続するファジィフィードフォワードコントローラ (FFC) を提案する。FFCの目的は，規範入力追従特性の 
改善であり，追従誤差信号を零収束させるよう制御ルール の後件部を調整する。ファジィコントローラでは，入力パ ラメータの意味に対応させて後件部変数を設定できるため, モータ特性などからパラメータの初期值を適切な值に予め 設定することが可能となる。また，十分な外乱抑圧特性を

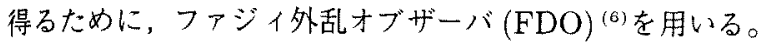
FDOについても周波数および位相差に対応した構成となっ ている。

以下では，FFC および FDO を用いた二自由度システム の構成法拉よび制御アルゴルズムについて詳述するととも に，試作システムを用いた奏測結果から提案システムの有 効性を確認している。

\section{2. 供試P UM}

〈2・1〉駆動システム図 1には, 超音波モー夕制御 実験システムのハードウェア構成を示す。駆動回路は, DDS(Direct Digital Synthesizer) と移相回路, アンプから なっている。DDSでは，指令に応じた周波数の正弦波信号 を発生させる。また，移相回路は DDSで得た正弦波信号に 対して，指令に応じた位相差のある正弦波信号を発生させ る。モータの回転角は，モー夕に直結した分解能 $3600[\mathrm{ppr}]$ のエンコーダからのパルスをカウントすることによって得 る。たたし、カウンタ回路入力時に 4 聥倍するため，角度 分解能は $14400[\mathrm{ppr}]$ となる。

なお，供試モー夕に用いた超音波モータの定格を表 $1 に$ 示す。

〈2・2〉動特性図 1に示した害験システムを用い， 無負荷の状態で過渡応答実験を行った。なお，本実験におけ

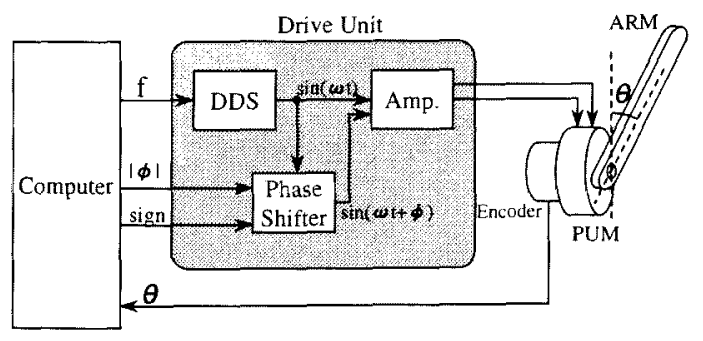

図 1 実験システム構成

Fig. 1. Experimental setup.

表 1 供試モ一夕の仕様

Table 1. Specifications of the tested PUM.

\begin{tabular}{c|c|c}
\hline Frequency & 40 & $\mathrm{kHz}$ \\
\hline Voltage & 100 & $\mathrm{~V}$ \\
\hline Rated power & 3 & $\mathrm{~W}$ \\
\hline Rated torque & 3.2 & $\mathrm{kgcm}$ \\
\hline Rated speed & 90 & $\mathrm{rpm}$ \\
\hline Weight & 0.24 & $\mathrm{~kg}$ \\
\hline
\end{tabular}

電学論C, 119 巻 11 号, 平成 11 年

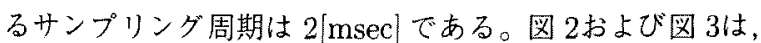
周波数㧍よび位相差に対する過渡応答特性である。図2は， 位相差を固定して周波数をステップ状に変化させた場合の モータの応答である。この場合は，6[msec] から $10[\mathrm{msec}]$ 以内に定常速度に達していることがわかる。たたし，位相 差を小さくすることによって速度の変動が大きくなってい る。図 3は，周波数を固定して位相差をステップ状に変化 させた場合の応答である。 (a) は位相差を $\pm \pi / 2[\mathrm{rad}]$ と

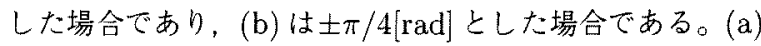
では，いずれの駆動周波数においても位相差の $-\pi / 2$ から

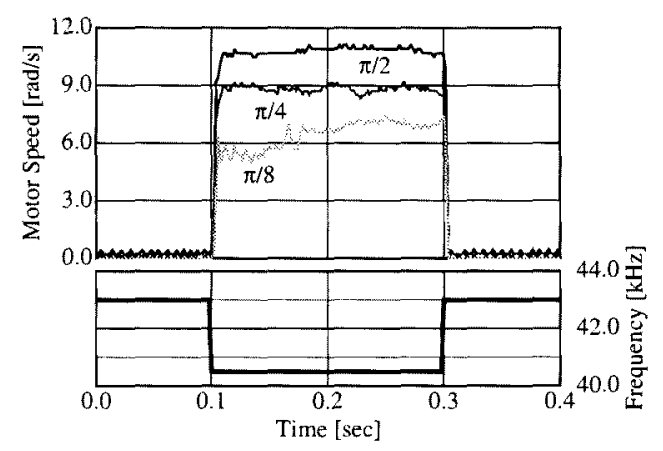

図 2 周波数ステップ入力に対する モー夕の応答

Fig. 2. Transient responses for step frequency input.

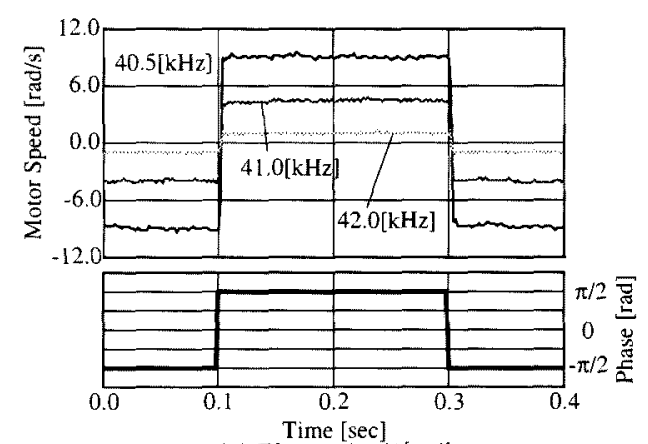

(a) Phase $= \pm \pi / 2[\mathrm{rad}]$

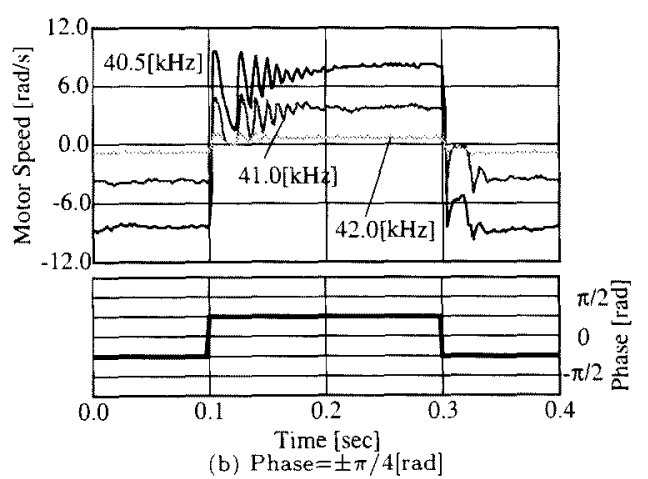

図 3 位相差ステップ入力に対する モータの応答

Fig. 3. Transient responses for step phase input. 
$\pi / 2 へ の$ 変化に対して安定に定常速度に達している。この とき，応答特性の整定時間は約 $2[\mathrm{msec}]$ であることを確認 している。これに対して (b) では，駆動周波数が低い高速 回転時に大きな振動が現れている。このような特性は，位 相差を $\pi / 8[\mathrm{rad}]$ にした場合も得られている。以上より，高 速回転域すなわち下限駆動周波数近傍での同相に近い範囲 の位相差操作は適切ではなく，駆動周波数操作により制御 を行う必要があることを表している。

\section{3. ファジィニ自由度制御システム}

超音波モー夕の駆動特性は，周波数においても位相差に おいても非線形性を有している。ここで，モータ駆動の非 線形性を補償して良好な追従特性を得るには，駆動周波数 と位相差を組み合わせた制御手法が有効である。

図 4は，提案するFDO システムの構成を示す。図より， FFC は駆動周波数を操作するための自己調整ファジィコン トローラ (F-FFC) と, 位相差を操作するための自己調整 ファジィコントローラ (P-FFC) からなる。各FFCには規 範位置信号 $\theta_{r}$, 規範速度信号 $\omega_{r}$, 規範加速度信号 $\alpha_{r}$, 掠上 び他方の FFCの出力を入力する。図中，Dは微分演算子 である。F-FFCの出力は PI コントローラの出力と加算さ れ，駆動周波数指令 $\mathrm{f}$ となる。一方，P-FFCの出力は回転 方向に応して符号付けされ位相差指令 $\phi$ なる。ここで，各 FFC の後件部変数は追従誤差信号 $e_{p}$ を零収束させるよう に調整される。FDOも，FFC と同様に周波数ファジィ外 乱オブザーバ (F-FDO) と位相差ファジィ外乱オブザーバ (P-FDO）からなる。各FDOには，モー夕の回転位置 $\theta$ ， 速度 $\omega$, 加速度 $\alpha$ ，および他方の FDO 出力を入力する。外 乱推定值は, 各FDO出力からそれぞれの制御量を減じるこ とによって得る。ここで，外乱推定をおこなうための FDO の制衔ルールは, FFCの制御ルールと同一の制御ルールが 複写される。以下, 各ファジィコントローラの制御アルゴ リズムを詳述する。

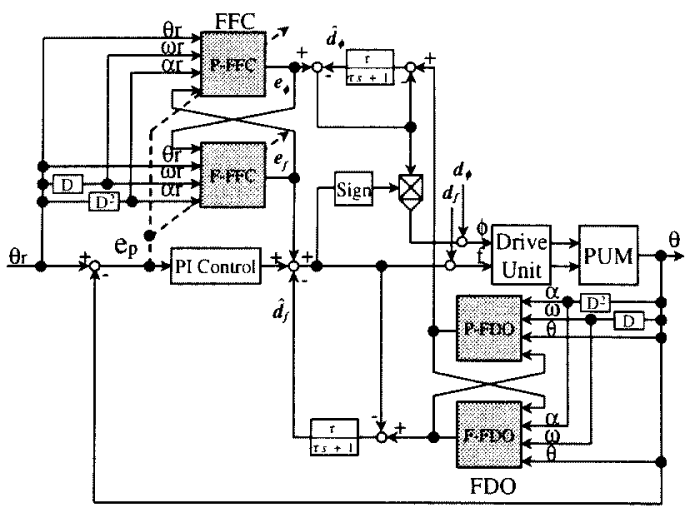

図 4 提案システム

Fig. 4. Block diagram of proposed two-degree-of-freedom positioning system with fuzzy controllers.

\section{〈3.1〉 FFC 各 FFCの制御ルールは, 次式のよ} うに記述される。

Rule: if $e_{\phi}$ is $A_{i}$ and $\theta_{r}$ is $B_{j}$ and $\omega_{r}$ is $C_{k}$ and $\alpha_{r}$ is $D_{l}$ then $e_{f}$ is $W_{i j k l}^{f}$

Rule: if $e_{f}$ is $A_{i}$ and $\theta_{r}$ is $B_{j}$ and $\omega_{r}$ is $C_{k}$ and $\alpha_{r}$ is $D_{l}$ then $e_{\phi}$ is $W_{i j k l}^{\phi}$

ここで, $A_{i}, B_{j}, C_{k}, D_{l}(i, j, k, l=0 \sim 4)$ はファジィ変数で あり， $W_{i j k l}^{f}$ は F-FFC， $W_{i j k l}^{\phi}$ は P-FFCにおけるシングル トンの後件部変数である。FFCは，機能上パラメー夕調整 部と推論部の二つの部分に分けられる。パラメータ調整部 は追從誤差信号を零収束するように後件部変数をチューニ ングする。推論部はパラメー夕調整部でチューニングされ た後件部変数を用いて簡略法により操作量を推論する。

まず，推論部へは規範位置信号 $\theta_{r}$ ，規範速度信号 $\omega_{r}$, 規 範加速度信号 $\alpha_{r}$ および他方の FFC 出力の 4 つのパラメー タが入力される。このとき，規範のパターンより求められる 各パラメータの範囲および周波数・位相差の操作範囲より， 各パラメータが正規化される。正規化された各パラメータ を図 5 に示す 5 つのラベルを持つ三角形のメンバシップ関 数でファジィ化する。ここで，4つの入力に対するグレー ドをそれぞれ $\mu_{i}(m), \mu_{j}(m), \mu_{k}(m), \mu_{l}(m)$ とすると，制御 ルールのダレード $\mu_{i j k l}(m)$ は次式のように積演算によって 求められる。これは，制御ルールのグレードを入力帰属度 に対して鋭敏にすることで，必要なルールの選択が明確に なるためである。

$$
\begin{array}{r}
\mu_{i j k l}^{s}(m)=\mu_{i}^{s}(m) \mu_{j}^{s}(m) \mu_{k}^{s}(m) \mu_{l}^{s}(m) \\
(s=f, \phi)
\end{array}
$$

パラメー夕調整部では，後件部変数を (2) 式で求めたグレー ド $\mu_{i j k l}^{s}(m)$ と追従誤差信号 $e_{p}(m)$ を用いて次の調整則によ りチューニングする。

$$
\begin{array}{r}
W_{i j k l}^{s}(m)=\gamma^{s} e_{p}(m) \mu_{i j k l}^{s}(m)+W_{i j k l}^{s}(m-1) \\
(s=f, \phi)
\end{array}
$$

ここで, $\gamma^{s}>0$ は各 FFCの学習ゲインである。後件部変 数は，ある初期值を持ち(3) 式によって更新されるが, 追 従䛊差信号が小さくなることによって更新量も小さくなり， 追従誤差信号が零収束した段階で一定値に収束する。コン トローラ出力は，(2) 式抢よび (3) 式で求められる制御ルー ルのグレードおよび後件部变数を用いて，次式により求め られる。

$$
e_{s}(m)=\frac{\sum \mu_{i j k l}^{s}(m) W_{i j k l}^{s}(m)}{\sum \mu_{i j k l}^{s}(m)} \quad(s=f, \phi)
$$

各 FFC の後件部変数を，次の条件に従って初期化する。

$$
\begin{aligned}
W_{i j k l}^{f}(m)= & \{i, j, k, l=0 \sim 4: 0\} \\
W_{i j k l}^{\phi}(m)= & \{j, k, l: \text { don't care, } \\
& i=0 \sim 4:-1.0,-0.5,0,0.5,1.0\}
\end{aligned}
$$


ここで，F-FFCの後件部変数 $W_{i j k l}^{f}$ は，零に初期化してい る。また，モー夕の駆動特性から低速時以外では位相差を 操作することが適切でないと考えられる。したがって，低 速時に位相差の変化がみられるように F-FFC 出力に応じ $\tau W_{i j k l}^{\phi}$ 在決定している。

〈3.2 $\mathbf{3}$ FDO FDOは，非線形な制御対象の入出 力関係から，外乱入力を推定する。外乱を推定するために は制御対象の逆システムが必要となる。一般に, 制御対象 の逆システムを予め知ることはできないが，本システムの 場合，チューニング後 FFCによりフィードフォワードパ ス内に等価的な逆システムが (1) 式の制御ルールとして構 成されるため，それを直接用いることができる。すなわち， FDOの制御ルールは次式で表される。

Rule: if $\hat{e}_{\phi}$ is $A_{i}$ and $\theta$ is $B_{j}$ and $\omega$ is $C_{k}$ and $\alpha$ is $D_{l}$ then $\hat{e}_{f}$ is $W_{i j k l}^{f}$

Rule : if $\hat{e}_{f}$ is $A_{i}$ and $\theta$ is $B_{j}$ and $\omega$ is $C_{k}$ and $\alpha$ is $D_{l}$ then $\hat{e}_{\phi}$ is $W_{i j k l}^{\phi}$

ここで， $\theta$ は出力位置， $\omega$ および $\alpha$ は, 次式で求められる近 似速度㧍上び近似加速度である。

$$
\omega=\frac{\tau_{\omega} s}{\tau_{\omega} s+1} \theta \quad \alpha=\frac{\tau_{\alpha} s}{\tau_{\alpha} s+1} \omega
$$

上式において， $\tau_{\omega} ， \tau_{\alpha}$ はそれぞれフィル夕時定数である。 FDOの各入力信号は, 図 5のメンバシップ関数によりファ ジイ化される。制卸ルールの㣪件部は，FFCで調整された 後件部の值が各サンプリングごとに逐次複写される。また， 推論結果は (4) 式と同様に求如られる。この結果は, 後件 部変数の調整が進行するとともに, FDO の外乱推定精度 も向上することを意味している。

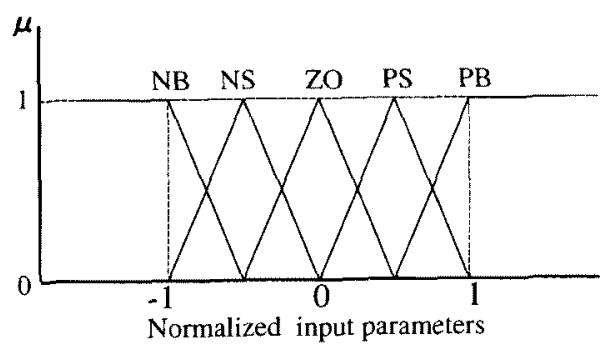

因 5 メンバシップ関数

Fig. 5. Membership functions.

\section{4. 実測結果}

提案したシステムの有効性を確認するために，図1に示 した実験システムを用いて応答特性を実測した。以下の実 験に执いては, サンプリング・制御間隔を $2[\mathrm{msec}]$, PI コ ントローラの比例ゲインを 36.0 ，積分ゲインを 0.1 とし， さらにF-FFCの学習ゲインを 1.0, P-FFCの学習ゲイン を 0.5 上している。なお，それぞれの学習ゲインは，応答 特性㧍よび誤差収束性に着目して試行錯誤により決定して いる。

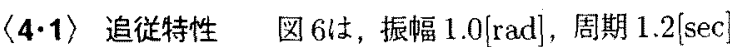
の二階微分可能な台形波状規範位置入力に対寸る無負荷時 の応答特性である。図より，制御初期段階では比較的大き な追従誤差が現れているものの，チューニングによって減 少していることがかかる。チューニング後には，规範入力 と出力位置はよく一致して㧈り，制御対象は主に F-FFC お よび P-FFCによって制御されていることがわかる。また， チューニング後には，規範位直のトラッキング動作時には 位相差がほほ士 $\pi / 2$ に保持され主として駆動周波数により 制御きれている。一方，位置決め時には，駆動周波数が上 限に保持されるため位相差により制御されていることがわ かる。このことは，F-FFCが主としてトラッキング時に㗢 き，位置決め時には P-FFCが機能していることを意味し ている。

図 7は，チューニング過程における制御ルールの代表的 な後件部変数の推移を表している。図より，後件部変数は チューニング初期段階で大きく変動した後に一定值に収束 していることがわかる。

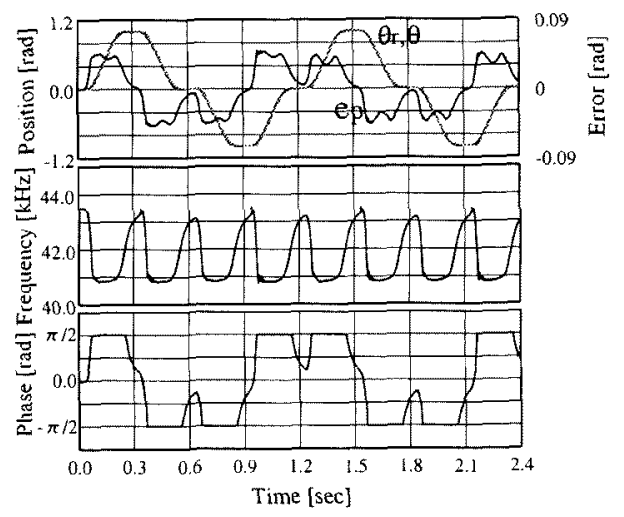

(a) Early stage of learning

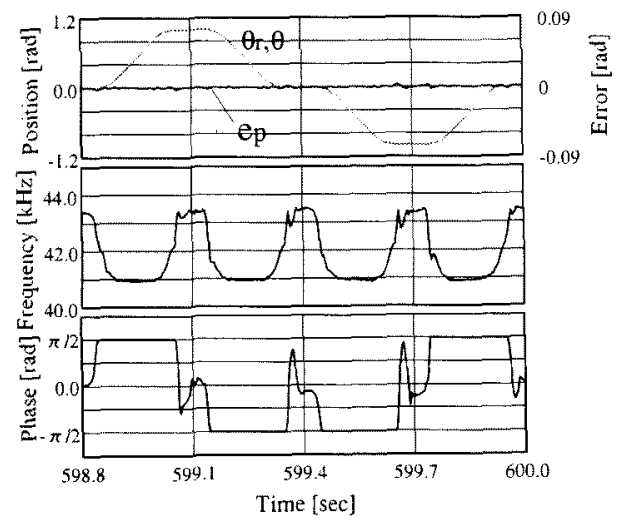

(b) After learning

図 $6 \mathrm{FFC}$ システムの応答特性

Fig. 6. Tracking performances for trapezoidal desired output under no load condition. 
図 8は，チューニング過程における自乗平均誤差を示し ている。図中，bが図6の実験に対応している。これによ り，25万回 $(500[\mathrm{sec}])$ 程度でほほチューニングが完了し， 自乗平均誤差が収束していることがわかる。また，図中a は，F-FFCのみを適用し，位相差については $\pi / 2 に$ に固 定して実験を行った場合の推移である。このとき，いくつ かの学習ゲインについて実験を行っているが、aは自乗平 均誤差が最も小さい值となった実験結果である。これより， 提案システムはF-FFCのみを用いた単独 FFCシステムよ りも誤差を小さくできることがわかる。さらに，cおよび $\mathrm{d}$ は，提案システムにおいて位相差の学習ゲインを 5.0 お よび 0.01 とした場合の推移である。このようにP-FFCの 学習ゲインを極端に変更した場合でも自乗平均誤差に大き な差違が見られず，比較的安定して誤差を減少させること ができた。

次に，本システムの沉化能力を確認するために，図6に示 した制御実験の後に得られた後件部変数を固定して異なる規 籁入力に対する応答特性を測定した。図 9は，周期 $2.0[\mathrm{sec}]$ の正弦波に振幅比 0.2 の 3 倍調波を重ねた波形を規範信号 とした場合の結果である。図中，モー夕回転方向変化時に 誤差が大きくなるものの，最大で 0.016[rad] 以下であり， ある程度の沉化能力を有していることがわかる。

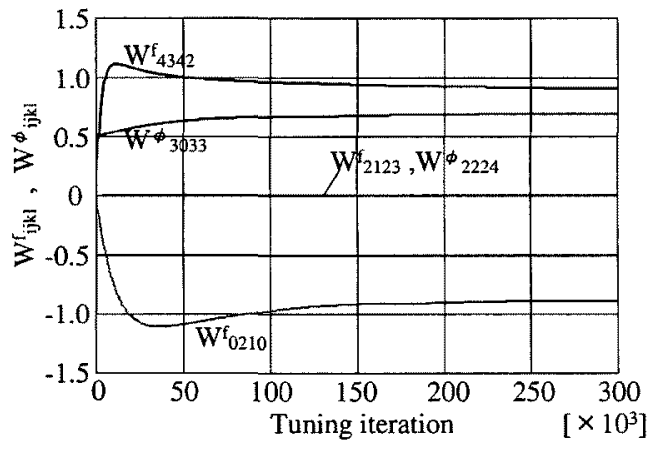

図 7 後件部変数の推移

Fig. 7. Responses of tuning parameters of both frequency and phase control rules.

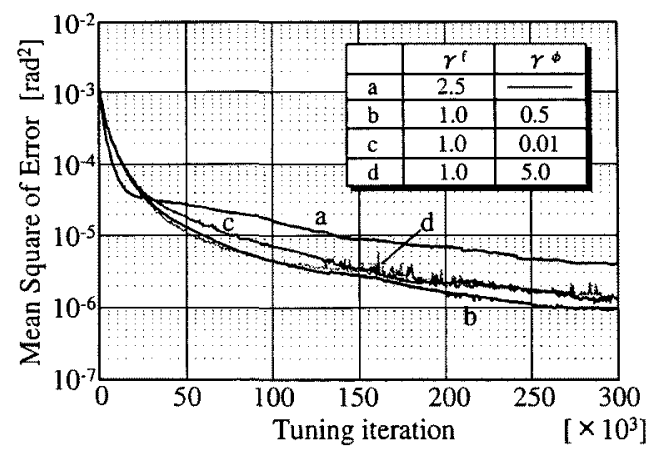

図 8 自乗平均誤差の推移

Fig. 8. Effect of tuning gain on mean square error
〈4-2〉外乱抑圧特性次に, 超音波モー夕に長さ $280[\mathrm{~mm}]$, 重さ $430[\mathrm{~g}]$ のアームを取り付けて実験を行っ た。この結果, モー夕の回転位置によって負荷が変動する ことになる。ここで，アームが垂直に倒立する位置を零と している。また，FDOの後件部は無負荷状態で台形波規 範入力に対して得られた FFCの後件部を用いる。図 10は, FFC システムとFDO システムの追従鿁差および各 FDO による外乱推定值を示す。図より，F-FDOの外乱推定值 $\hat{d}_{f}$ はアームが水平位置に近くなるはど值が大きくなり，ま

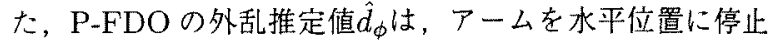
させてから再び回転させる際に急激に大きくなっているこ とがわかる。追従誤差は，FDOを用いた場合の方が FFC のみの場合に比較して誤差を小さくできていることがわか

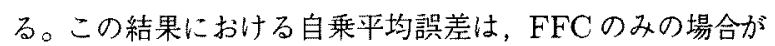
$1.41 \times 10^{-3}\left[\mathrm{rad}^{2}\right]$ であるのに対して提案したシステムで は $1.245 \times 10^{-4}\left[\mathrm{rad}^{2}\right]$ とおよそ1/10となって扔り，これ からもFDOの有効性が確認できた。

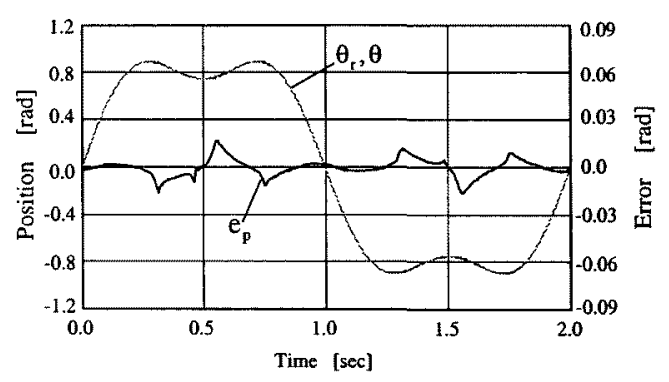

図 9 チューニング時と異なる規範入力に対する 応答特性

Fig. 9. Responses for different desired output.

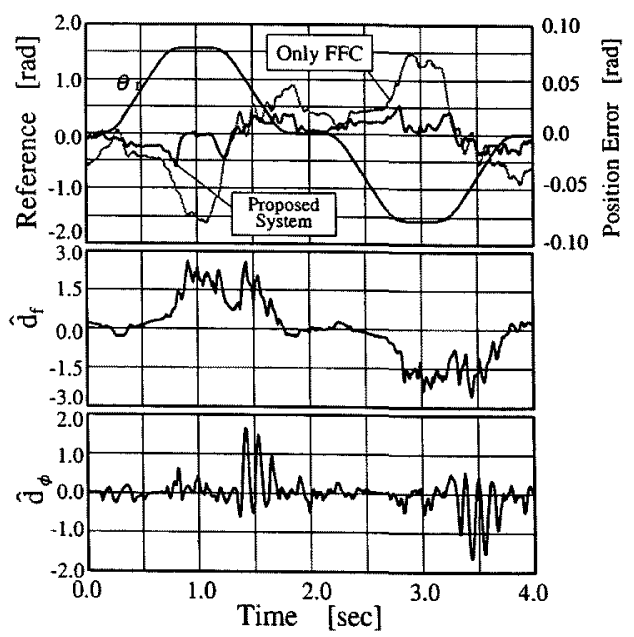

図 10 外乱負荷を与えた場合の FFC 㧍よび FDO システムの応答

Fig. 10. Effect of FDO for disturbance input. 


\section{5. まと め}

本稿では，良好な追従特性と充分な外乱抑圧特性を両立す る超音波モータ位置サーボシステムとして，FFCと FDO を用いた二自由度システムを提案している。FFC は周波 数と位相差を操作量とする二つの自己調整ファジィコント ローラからなり，一方のコントローラの出力を他方の入力 とすることにより，操作量の適切な組み合わせが実現でき る。FDOはFFCで調整されたルールを直接用いることで 外乱を推定している。試作した位置サーボシステムの実測 結果より以下のことが明らかとなった。

（1） FFC は，二階微分可能な規範位置入力に対してシ ステムの追従特性を著しく改善できる。このとき規 範位置入力に対するトラッキング動作時には主とし て周波数を，位置決動作時には位相差を操作して おり, 両操作量の適切な組み合わせが得られている。

（2）また，周波数と位相差の二つの自己調整ファジィ コントローラの学習ゲインのバランスを変化させて も，安定したチューニング結果が得られた。

（3）提案した FFC はチューニング時とは異なる規範 位置入力に対しても有効であり，規範位置入力に対 する汎化能力を有していることが確かめられた。

（4）FDOは加えられた外乱入力を推定することが可 能であり，システムの外乱抑圧特性の向上に有効で あることが確かめられた。

(平成 11 年 2 月 25 日受付, 同 11 年 8 月 4 日再受付)

\section{文献}

（1）秋山：「超音波モータ/アクチュエータ」トリケップス, 1986

(2) T.Kamano, T.Suzuki, T.Kuzuhara, M.Tomizuka:" Adaptive Feedfoward Control for Positioning System with Progressive Wave Type Ultrasonic Motor",Electric Machines and Power Systems,23,583-595,1995

（3）千住·宮里·上里:「ハイブリッド制御による超音波モータの高速・高 精度位置決め制御」, 電学論 D, Vol.115, No.11，pp.1333-1340 1995

（4）泉野·中岡:「ファジィ推論コントローラを用いた超音波モー夕直接駆 動位置決め制御システム」, 電学論D，Vol.115，No.11，1347-1356， 1995

（5）鈴木・鎌野·安野:「ファジィ制御による超音波モー夕高性能位置決 めシステム」,超音波T E C H N O，Vol.7，No.10，43-47，1995

（6）福見・鎌野·鈴木·安野・片岡:「ファジィ二自由度位置決めシステム の構成法」, 電気学会論文誌, Vol.117-C, No.11, pp.1615-1622 1997

（7）千住・宮里・上里:「ニューラルネットワークによる超音波モータの 位置制御」，電学論D, Vol.116, No.10, pp.1059-1066, 1996

（8）福田・鎌野·鈴木·安野:「周波数㧍よび位相差ニューラルネット ワークを用いた超音波モー夕位置サーボシステムの高精度化」，日 本A EM学会誌, Vol.6, No.4, pp.350-357, 1998
福田耕治（正員） 1963 年 5 月 10 日生。1988年 3 月豊橋技 術科学大学生産システム工学専攻修士課程修了。 1991 年阿南工業高等専門学校制御情報工学科助 手, 1998 年同講師となり, 現在に至る。電気学 会, 計測自動制御学会, 精密工学会, 日本 AEM 学会会員

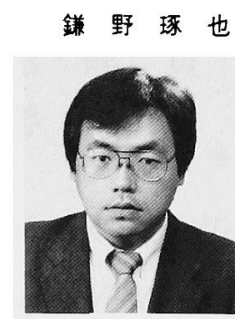

正員） 1957 年 3 月 1 日生。 1982 年 3 月九州大 学大学院工学研究科電気工学専攻修士課程修了。 1983 年 9 月同研究科博士課程退学。同年 10 月徳 島大学工学部電気工学科助手, 1989 年 12 月電気 電子工学科助教授となり、現在に至る。電気学会, 計測自動制御学会, システム制御情報学会, 日本 ロボット学会, 日本ファジィ学会会員。
安 野

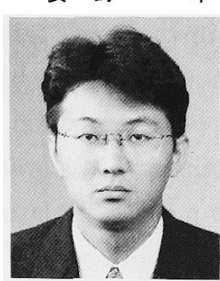

卓（正員） 1968 年 7 月 1 日生。1993 年 3 月徳島大 学大学院工学研究科電気電子工学専攻博士前期課 程修了。1993 年 12 月同研究科システム工学専攻 博士後期課程退学。1994 年 1 月徳島大学工学部 電気電子工学科助手, 現在に至る。1993 年度計 測自動制御学会学術奖励賞受賞。電気学会, 計測 自動制御学会, システム制御情報学会会員。

鈴木茂行（正員） 1939 年 3 月生。1966 年 3 月徳島大学

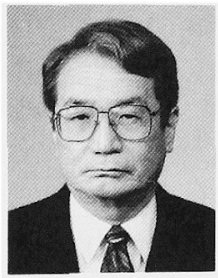
大学院工学研究科電気工学専攻修士課程修了。徳 島大学工学部電気工学科助手, 講師, 助教授を経 て, 現在電気電子工学科教授。各種電動機の制御 法, 自然エネルギー利用のための制御法の開発等 の研究に従事。工学博士。電気学会, 電子情報通 信学会, 計測自動制御学会, システム制御情報学 会会員。 